\title{
The effect of Isoprinosine treatment on persistent infection of Balb/c mice infected with murine gammaherpesvirus 68
}

\author{
O. JANÍČKOVÁ ${ }^{1}$, L. ANČICOVÁ ${ }^{1}$, K. BRIESTENSKÁ ${ }^{1}$, J. MISTRÍKOVÁ ${ }^{1,2^{*}}$ \\ ${ }^{1}$ Faculty of Natural Sciences, Department of Microbiology and Virology, Comenius University, Mlynská dolina, Ilkovičova 6, 84215 \\ Bratislava 4, Slovak Republic; ${ }^{2}$ Institute of Virology, Biomedical Research Center Slovak Academy of Sciences, Dúbravská cesta 9 , \\ 84505 Bratislava, Slovak Republic
}

Received April 4, 2016; revised August 30, 2016; accepted January 13, 2017

\begin{abstract}
Summary. - We demonstrated the positive effect of Isoprinosine treatment on persistent infection of Balb/c mice with murine gammaherpesvirus 68 (MHV-68). Increased number of leukocytes, increased percentage of neutrophils, elevated levels of virus-neutralizing (VN) antibodies, reduced number of atypical lymphocytes and reduced virus titers were detected in the examined organs after a 14-day treatment. The positive effect of Isoprinosine therapy vanished after 120-150 days. After this interval, we demonstrated lower numbers of leukocytes, lower levels of $\mathrm{VN}$ antibodies and an increased number of atypical lymphoid monocytes in the Isoprinosine-treated group. Immunological parameters correlated with increased titers of virus in all investigated organs. Evidence of immunostimulation was demonstrated by lower incidence of tumor formation (7.5\%) in the group of MHV-infected and Isoprinosine-treated mice in comparison to group without Isoprinosine treatment (17.5\%). The presented results showed that Isoprinosine therapy had a positive impact on persistent infection of mice with MHV-68, but this effect was time-limited. The improvement of the investigated parameters lasted for five months only. Our presented results confirmed that each treatment with Isoprinosine should be repeated and must be long-term in some chronic infections.
\end{abstract}

Keywords: MHV-68; Isoprinosine; immunity; reactivation of latent virus; tumors

\section{Introduction}

Isoprinosine (Inosine acedoben dimepranol) is known as a drug with immunomodulatory and antiviral effects, which is registered in 75 countries all over the world and has been used for more than 20 years (Campoli-Richards et al., 1986). Originally introduced in 1974 by Gordon for treatment of geriatric patients, it was later found to have a significant immunostimulating effect. Isoprinosine was also used as a very effective antiviral drug in combating herpes virus infection and is still regarded as the forerunner of acyclovir (Gordon $e t$ al., 1974). Immunomodulatory effects of Isoprinosine results

*Corresponding author. E-mail: virumis@savba.sk; phone: + 421-2-60296-485.

Abbreviations: $\mathrm{dpi}=$ days post infection; IS = Isoprinosine; MHV- 68 = murine gammaherpesvirus 68; VNA = virus neutralization assay; $\mathrm{EBV}=$ Epstein-Barr virus in antiviral activity, which can be demonstrated in vitro and in vivo (Campoli-Richards et al., 1986).

In vivo, Isoprinosine is believed to stimulate the production of lymphokines. This hypothesis was confirmed by a number of experiments, which demonstrated the increased amounts of lymphokines (IL-1, IL-2) as wells as an increase of blood mononuclear cells in patients following treatment with Isoprinosine (Nakamura et al., 1983; Tsang et al., 1985). It was also shown that the antiviral and immunomodulating activity of Isoprinosine increased a number of parameters of either specific or non-specific (cell-mediated) immunity (Petrisková et al., 2002). Isoprinosine stimulates the function of blood mononuclear cells (PBMC), which leads to increased response against different mitogens (Jacobsen and Greenspan, 1982; 1983). The antiviral activity of Isoprinosine was confirmed to result in inhibition of replication of DNA and RNA viruses and in improvement of cell-mediated immunity (Simon and Glasky, 1978). An inhibition of replication was demonstrated for herpes simplex virus, cytomegalovirus, adenovirus, po- 
liovirus, poxvirus, influenza A and B, rhinovirus, echovirus, rabies virus, encephalomyocarditis virus and eastern equine encephalitis virus (Muldoon et al., 1972; Ginsberg et al., 1973; Gordon et al., 1974; Hernández-Jáuregui et al., 1980; Ohnishi et al., 1983). Antiviral activity was also demonstrated against monkey rotavirus, where the level of inhibition was dependent on the concentration of Isoprinosine (Linhares et al., 1989). Effective inhibition of replication of Newcastle disease virus was achieved by combining Isoprinosine and immunomodulator KLP-602 (Malaczewska and Rotkiewicz, 2005). Immunomodulatory and antiviral effects of Isoprinosine have been tested in vivo in experimental animals infected with DNA and RNA viruses, and with various doses of medicated Isoprinosine. The recommended daily dose is $50 \mathrm{mg}$ of Isoprinosine per kg. Positive clinical improvements have been observed with infection by herpes simplex virus, subacute sclerosing panencephalitis, genital warts, flu, in herpes zoster virus infection, hepatitis $\mathrm{B}$, as well as in homosexual men with persistent generalized lymphadenopathy. Statistically important therapeutic results were reported in the treatment of tropical measles, but not in measles. A variety of studies deal with the therapeutic effects of Isoprinosine in infectious diseases and autoimmune diseases (Campoli-Richards et al., 1986; Sadowska-Wróblewska et al., 1988). The treatment of patients infected with human immunodeficiency virus maintains the standard levels of $\mathrm{CD}^{+}$and $\mathrm{CD}^{+} \mathrm{T}$-lymphocytes, and increases the amount of leukocytes (De Simone et al., 1989). Studies have also shown a positive effect of Isoprinosine in the treatment of various skin diseases that are caused by infectious viruses (herpes simplex, herpes zoster and human papillomavirus-induced genital warts) (Matusiak and Szepietowski, 2010). Therapeutic efficacy of Isoprinosine was confirmed especially in papillomavirus infections. The treatment of genital warts represents a safe alternative of systematic therapy (Mohanty and Scott, 1986; Georgala et al., 2006). Isoprinosine can also be used in patients with varicella-zoster (VZ) infection and has been tested in patients with acute hepatitis B. Under the influence of this drug, normalization of biochemical markers and liver functions occurred, leading to overall recovery of patients (Karimov, 2004).

However, Isoprinosine affects the whole immune system and has also been tested in tumor diseases. In patients with primary tumors (lung cancer, mammary adenocarcinoma, melanoma), all reduced parameters returned to normal after application of Isoprinosine (Tsang et al., 1983).

Isoprinosine was also tested with respect to Epstein-Barr virus (EBV) that causes lymphoproliferative disorders. The study was focused on the ability of Isoprinosine to increase lymphocyte response against EBV antigens and EBV-transformed lymphocytes (Sundar et al., 1985).

Isoprinosine is also known under the trade name Imunovir. The generic name of the molecule is inosine acedoben dimepranol or methisoprinol, also referred to as inosine pranobex or inosiplex (Hrubiško, 2009). All recent reports demostrated that Isoprinosine has immunomodulation, antiviral and antiproliferative effect (Campoli-Richards et al., 1986; Petrova et al., 2010; Samuel, 2011).

MHV-68, a murine virus, serves as a model to study the pathogenesis (immunology and oncogenesis) of EBV in experimental animals (Blaškovič et al., 1980; Mistríková et al., 2000; Čipková-Jarčušková et al., 2013). It allows us to monitor the progress of virus distribution in different stages, i.e. in acute and chronic infection (Stevenson and Doherty, 1998). MHV-68, namely its genetic and biological properties, is very similar to EBV, both possessing the characteristics of human gammaherpesviruses (Sunil-Chandra, 1992). In view of the fact that infections with gammaherpesviruses are frequent in the population and Isoprinosine is often used as an immunomodulatory agent, we decided to test the effect of Isoprinosine treatment in Balb/c mice infected with the MHV-68.

Epstein-Barr virus is a human gammaherpesvirus that induces persistent infection and is associated with several lymphoproliferative disorders, including infectious mononucleosis (IM). IM is accompanied by abnormalities of the immune system, including a temporary reduction in the activity of the immune system. Due to this observation we assume that Isoprinosine may be very useful for therapy of immunosupression following gammaherpesvirus infection.

The aim of this work was to investigate the immunomodulatory effect of Isoprinosine treatment of chronic infection of $\mathrm{Balb} / \mathrm{c}$ mice focused on the following parameters:

- to compare the number of leukocytes and percentage of neutrophils in the blood of infected mice either treated or not treated with Isoprinosine

- to compare differential blood cell count (DBC) at different stages of infection in both animal groups

- to determine the virus-neutralizing antibody titer in both groups

- to determine the presence of the virus in different organs of infected and drug-treated mice

- to confirm the efficacy of Isoprinosine and/or characterize its role in persistent infection and in reactivation of latent virus as well as on lymphoproliferative processes related to the development of virus-related lymphomas.

\section{Materials and Methods}

Cells, viruses and mice. Vero cells and NIH 3T3 cells were maintained in Dulbecco's modified Eagle's medium (DMEM) supplemented with $9 \%$ of heat-inactivated fetal bovine serum (FBS), glutamine, penicilline and streptomycine. Cell cultures were grown in a $5 \% \mathrm{CO}_{2}$ humidified atmosphere at $37^{\circ} \mathrm{C}$. MHV- 68 stock (isolated from Myodes glareolus) was prepared by virus propagation on NIH 3 T3 cells, while titers of infectious viruses were determined 

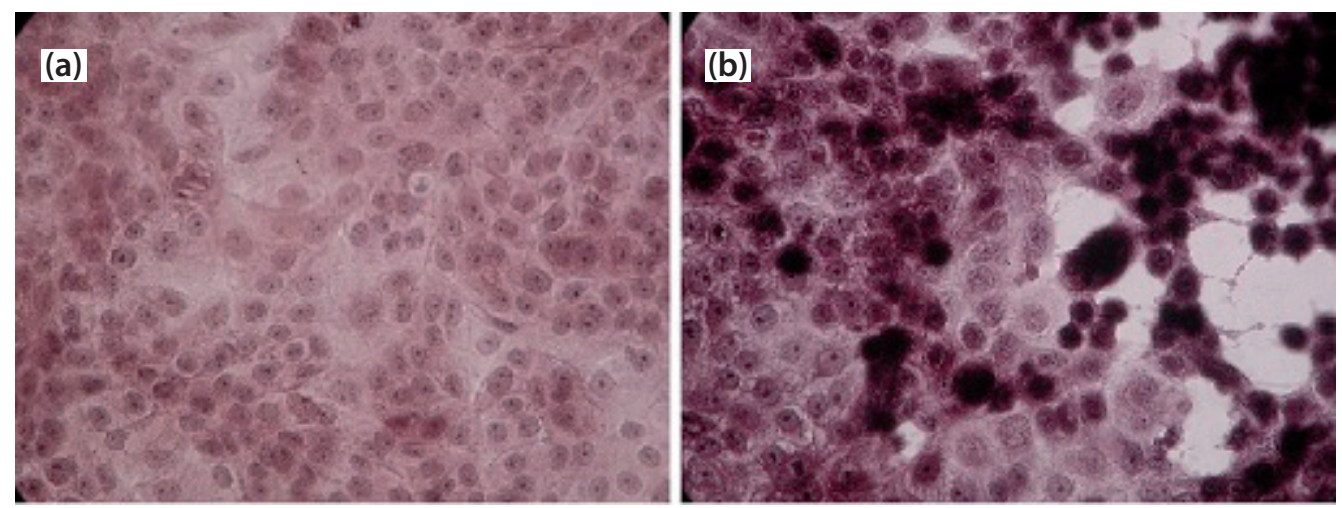

Fig. 1

Infection of Vero cells with MHV-68 from mouse tissues

(a) Control non-infected Vero cells; (b) Vero cells infected with suspension from organs of Balb/c mice infected with MHV-68.

by plaque assay on Vero cells. Six-weeks old female Balb/c mice were supplied by the Faculty of Veterinary Medicine, Brno, Czech Republic.

Coumpound. Isoprinosine (4-acetamidobenzoic acid;9[(2R,3R,4S,5R)-3,4-dihydroxy-5-(hydroxymethyl)oxolan-2-yl]$3 \mathrm{H}$-purin-6-one;1-(dimethylamino)propan-2-ol) is used in the treatment of a variety of viral infection. For peroral aplication, $500 \mathrm{mg}$ tablet (Ewofarma) was diluted in distilled water.

Infection. Six-week-old female Balb/c mice were intranasally infected with $2 \times 10^{4} \mathrm{PFU}$ of MHV-68 per mouse in total inoculum volume of $20 \mu \mathrm{l}$, under light anesthesia. 100 mice were used in our experiment, 70 mice were infected with MHV-68, and 35 of 70 infected mice received 14 doses of Isoprinosine $(2.5 \mathrm{mg} /$ mouse/day), administered perorally by catheter. Control group of 30 mice received intranasally $20 \mu \mathrm{l}$ of phosphate buffered saline (PBS).

Blood sample analysis. Blood for serum preparation and leukocytes examination was taken from sinus orbitalis. Heparinized blood was used to determine the total leukocyte count and differential blood cell count (DBC count). The total leukocyte count was determined after staining with Türck's solution. In order to determine DBC count, air dried smears were stained for 10 min with May-Grünwald solution and then for $15 \mathrm{~min}$ with Giemsa-Romanowski solution. The stain solution was removed by rinsing with tap water and the smears were examined microscopically using a 100x magnification.

Virus-neutralization assay was performed with 2 -fold dilutions of heat-inactivated sera from infected mice. For neutralization, $1000 \mathrm{PFU}$ of appropriate virus was added. The virus-serum mixtures were incubated at $37^{\circ} \mathrm{C}$ for $30 \mathrm{~min}$ and then inoculated on Vero cell cultures according to the growth requirements of the respective virus. The last dilution of serum that was able to prevent virus infection in cell culture was considered as the titer of virusneutralization antibodies.

\section{Results}

The aim of this work was to investigate the effect of Isoprinosine therapy on persistent MHV-68 infection in Balb/c mice. In our experiment were used $100 \mathrm{Balb} / \mathrm{c}$ mice, 70 mice were infected with MHV-68, 35 of 70 infected mice received Isoprinosine and another 30 mice served as controls. The

Table 1. Number of leukocytes and percentage of neutrophils during chronic phase of infection with MHV-68 after Isoprinosine treatment in comparison to control (non-infected) mice

\begin{tabular}{|c|c|c|c|c|c|c|}
\hline & \multicolumn{3}{|c|}{ Neutrophils } & \multicolumn{3}{|c|}{ Leukocytes } \\
\hline & $\mathrm{C}$ & V & $\mathrm{V}+\mathrm{I}$ & $\mathrm{C}$ & V & V+I \\
\hline $60 \mathrm{dpi}$ & 4 & 13 & 32 & 5,600 & 4,350 & 6,450 \\
\hline $90 \mathrm{dpi}$ & 5.3 & 13.5 & 32.5 & 7,700 & 4,400 & 5,900 \\
\hline $120 \mathrm{dpi}$ & 6.5 & 15 & 30 & 9,300 & 8,400 & 11,500 \\
\hline $150 \mathrm{dpi}$ & 10.5 & 15.5 & 30 & 8,300 & 8,900 & 16,750 \\
\hline $180 \mathrm{dpi}$ & 12 & 16 & 10 & 9,900 & 18,000 & 12,000 \\
\hline $210 \mathrm{dpi}$ & 8.7 & 11.5 & 7.5 & 11,300 & 17,100 & 10,600 \\
\hline $240 \mathrm{dpi}$ & 10.5 & 10 & 9 & 12,500 & 11,500 & 8,400 \\
\hline
\end{tabular}

dpi $=$ days post infection; $\mathrm{V}=$ MHV-68; $\mathrm{V}+\mathrm{I}=\mathrm{MHV}-68+$ Isoprinosine; $\mathrm{C}=$ non-infected (control) mice. 
Table 2. Percentage of atypical lymphocytes and titer of VN-antibodies during chronic phase of infection with MHV-68 after Isoprinosine treatment in comparison to control (non-infected) mice

\begin{tabular}{|c|c|c|c|c|c|c|}
\hline & \multicolumn{3}{|c|}{ Atypical lymphocytes } & \multicolumn{3}{|c|}{ Titer of VN antibodies } \\
\hline & $\mathrm{C}$ & $\mathrm{V}$ & $\mathrm{V}+\mathrm{I}$ & $\mathrm{C}$ & $\mathrm{V}$ & $\mathrm{V}+\mathrm{I}$ \\
\hline $60 \mathrm{dpi}$ & 0 & 10 & 1 & 0 & 32 & 64 \\
\hline $90 \mathrm{dpi}$ & 0 & 9 & 0 & 0 & 32 & 64 \\
\hline $120 \mathrm{dpi}$ & 0 & 10 & 1 & 0 & 32 & 64 \\
\hline $150 \mathrm{dpi}$ & 0 & 8 & 0 & 0 & $16-32$ & $16-32$ \\
\hline $180 \mathrm{dpi}$ & 0 & 15 & 32 & 0 & 512 & 128 \\
\hline $210 \mathrm{dpi}$ & 0 & 6 & 12 & 0 & 512 & 128 \\
\hline $240 \mathrm{dpi}$ & 0 & 6 & 12 & 0 & 512 & 8 \\
\hline
\end{tabular}

dpi = days post infection; $\mathrm{V}=\mathrm{MHV}-68 ; \mathrm{V}+\mathrm{I}=\mathrm{MHV}-68+$ Isoprinosine $\mathrm{C}=$ non-infected (control) mice.

treated group received $2.5 \mathrm{mg} /$ day of Isoprinosine administered orally for 14 days. At regular intervals (60, 90, 120, 150, 180,210 , and 240 days post infection (dpi)), we compared the group of untreated but infected mice with the group of Isoprinosine-treated and MHV-68-infected mice. The monitored parameters were total leukocyte count (percentage of neutrophils, the proportion of atypical lymphocytes) as well as the virus-neutralizing antibody titers (VNT). The purpose of the comparison of these parameters was to confirm the effect of Isoprinosine on the course of persistent infection and its influence on reactivation of persistent infection and on the subsequent lymphoproliferative process (assessed by lymphoma formation). At regular intervals (60, 90, 120,
$150,180,210$, and $240 \mathrm{dpi}$ ), the infected mice in both groups (treated and non-treated with Isoprinosine) were sacrificed and their organs were investigated for virus presence using virus titration method (Fig. 1). Blood samples were taken to count leukocyte numbers and to determine differential blood cell count as well as VN antibody titer.

The antiviral and immunomodulatory effect of Isoprinosine has been confirmed in experimental MHV-68 infection. In response to the ongoing virus replication in the body, the level of leukocytes may increase along with the percentage of neutrophils and appearance of atypical lymphoid monocytes. Moreover, VN antibodies were formed simultaneously and their titer increased with the duration of infection.

Table 3. Detection of virus in organs of mice chronically infected with MHV-68 after Isoprinosine treatment

\begin{tabular}{|c|c|c|c|c|c|c|c|c|}
\hline Titration of organs & & $60 \mathrm{dpi}$ & 90 dpi & 120 dpi & 150 dpi & 180 dpi & 210 dpi & $240 \mathrm{dpi}$ \\
\hline \multirow{2}{*}{ Peritoneal macrophages } & $\mathrm{V}$ & + & + & + & - & - & + & - \\
\hline & $\mathrm{V}+\mathrm{I}$ & - & - & - & - & - & + & - \\
\hline \multirow{2}{*}{ Lymphatic nodes } & $\mathrm{V}$ & - & + & + & - & - & + & - \\
\hline & $\mathrm{V}+\mathrm{I}$ & - & - & - & - & - & - & - \\
\hline \multirow{2}{*}{ Kidneys } & $\mathrm{V}$ & + & + & + & + & - & - & ++ \\
\hline & $\mathrm{V}+\mathrm{I}$ & - & - & - & + & ++ & - & ++ \\
\hline \multirow{2}{*}{ Heart } & $\mathrm{V}$ & ++ & + & + & +++ & ++ & - & + \\
\hline & $\mathrm{V}+\mathrm{I}$ & - & - & - & + & + & - & - \\
\hline \multirow{2}{*}{ Thymus } & $\mathrm{V}$ & - & - & + & - & - & - & + \\
\hline & $\mathrm{V}+\mathrm{I}$ & - & - & - & - & - & - & - \\
\hline \multirow{2}{*}{ Spleen } & $\mathrm{V}$ & - & - & + & + & + & + & ++ \\
\hline & $\mathrm{V}+\mathrm{I}$ & - & - & - & + & + & + & ++ \\
\hline \multirow{2}{*}{ Bone marrow } & $\mathrm{V}$ & - & - & - & - & - & + & - \\
\hline & $\mathrm{V}+\mathrm{I}$ & - & - & - & - & - & + & - \\
\hline \multirow{2}{*}{ Liver } & $\mathrm{V}$ & - & - & - & + & ++ & ++ & ++ \\
\hline & $\mathrm{V}+\mathrm{I}$ & - & - & - & - & ++ & ++ & ++ \\
\hline \multirow{2}{*}{ Lungs } & $\mathrm{V}$ & - & - & + & + & ++ & + & - \\
\hline & $\mathrm{V}+\mathrm{I}$ & - & - & - & + & + & + & - \\
\hline
\end{tabular}

dpi = days post infection; $\mathrm{V}=\mathrm{MHV}-68 ; \mathrm{V}+\mathrm{I}=\mathrm{MHV}-68+$ Isoprinosin; $(+)$ 10\%, (++) 50\%,(+++) 75\%; CPE (cytophatic effect) on the Vero cells infected with $10 \%$ suspension from organs of infected $\mathrm{Balb} / \mathrm{c}$ mice and treated with Isoprinosine. 
As shown in Tables 1 and 2, within 60-120 days after treatment with Isoprinosine, MHV-68-infected mice showed increased level of leukocytes, elevated percentage of neutrophils, and increased levels of VN antibodies in comparison to untreated ones, but a decreased level of atypical lymphoid monocytes. In the treated group, the VN antibody titer reached the maximum value at 180 and $210 \mathrm{dpi}$. At later time points (180-240 dpi), a significant increase of VN antibody levels was observed in the group of infected mice not treated with Isoprinosine. This may indicate reactivation of the virus at the given stage of infection. In contrast, the enhancement of VN antibody levels in Isoprinosine-treated group was insignificant, which may indicate a suppression of virus reactivation elicited by Isoprinosine therapy.

As shown in Table 3, the virus levels in organs of chronically infected mice have decreased during 60-150 days following the Isoprinosine treatment. In these mice, we detected only very low levels of reactivated virus in the tested organs. At these time points, treated mice gained weight when compared with non-treated controls. In the untreated group of infected mice the virus was present in kidneys, heart, peritoneal macrophages and lymphatic nodes at 60-90 dpi. At 120-150 dpi, the virus was demonstrated in almost every organ except for bone marrow and liver. As a result of persistent infection with the MHV-68, infected mice formed tumors.

Evidence of immunostimulation by Isoprinosine therapy was demonstrated by lower incidence of tumor formation in Isoprinosine-treated mice. In this group, we detected lower tumor incidence at 180, 270 and $450 \mathrm{dpi}$ (7.5\%), in comparison with the group of $\mathrm{MHV}$-infected mice without Isoprinosine treatment at $180,210,300,310,320,450$, and 455 dpi (17.5\%). A decrease in the number of tumors from 7 to 3 was also observed after immunostimulatory therapy. Because of low number of animals used in the study, these results cannot be considered statistically significant; however, they represent a posssibility that Isoprinosine therapy will be beneficial in the prevention of tumors induced by infection with gammaherpesviruses.

\section{Discussion}

Isoprinosine is used in the clinical practice as an immunostimulant with antiviral effect (Gordon et al., 1974). In the state of immunosuppression, Isoprinosine restarts the lymphocyte function, enhances blastogenesis in monocyte population, stimulates cytotoxic T-lymphocytes and NK cells, and enhances the production of IgG, IFN gamma, IL-1 and IL-2 (Hersey et al., 1984). Moreover, it reduces the production of proinflammatory cytokines and stimulates the chemotaxis of neutrophils, monocytes and macrophages (Hadden et al., 1979).

The human gammaherpesvirus EBV establishes lifelong latency in B-lymphocytes in infected individuals, who count more than $90 \%$ of human population. It poses a health risk for immunocompromised individuals, since it is associated with several lymphoproliferative diseases and development of malignancies. (Rickinson and Kieff, 2007).

There are currently only few reports documenting the effect of Isoprinosine on gammaherpesviruses. Therefore, studies in a well-established mouse model, analogous to EBV, that is used to study the pathogenesis and immunology in the natural host (Blaškovič et al., 1980; Stevenson and Doherty, 1998), can contribute to our understanding of the effects of Isoprinosine on such infection.

The main goal of our study was to analyze the effect of Isoprinosine on the replication of MHV-68 in vivo, to quantify the level of blood leukocytes and their subpopulations, the production of antiviral neutralization antibodies and to determine the presence of the virus in different organs during the chronic phase of the infection. Isoprinosine affected selected parameters of the immune response and it reduced the virus levels in the organs of infected mice immediately after premedication, with the effect lasting $120 \mathrm{dpi}$. Mice were premedicated for 14 days, which is the time recommended for treatment of recurrent infections (Campoli-Richards et al., 1986). We did not record any visible symptoms in mice during the acute infection. This is in contrast with the data obtained by Sunil-Chandra et al. (1992) who observed symptoms such as ruffled fur, emaciation and severe weakness during the acute phase of infection following intranasal inoculation of Balb/c mice. Later on during infection (90 dpi), Isoprinosine-treated animals showed apparent weight-gain, which was noticeable at dissection as an increased amount of abdominal fat. In contrast to infected but untreated mice, infected and Isoprinosine-treated mice were bigger (data not shown). In addition, no virus was detected by virus titration in any of the analyzed organs of infected and Isoprinosine-treated mice during the chronic phase of infection (60-120 dpi). In animals that were infected but untreated, virus was detected in kidneys, heart and peritoneal macrophages at $90 \mathrm{dpi}$, and in almost all organs, with the exception of liver and blood marrow, at $120 \mathrm{dpi}$.

Based on the above results, we can conclude that Isoprinosine had a positive effect on suppression of virus replication at 60-120 dpi, e.g. 2-60 days after the end of the treatment. These results correlate with the data published by CampoliRichards et al. (1986).

We next tested the organs for the presence of the virus at later time points of chronic infection, 150-180 dpi. At this time we detected the presence of the virus in kidney, heart, liver and lung in infected animals, thus confirming the hematogenic spread of MHV-68 in the organism. At $210 \mathrm{dpi}$, the virus was detected in several lymphatic organs - peritoneal macrophages, spleen and in the bone marrow. At this time point, we detected virus also in infected and Isoprinosinetreated mice, which indicates that the therapy by Isoprinosine 
does not have a long-term effect on the suppression of latent virus reactivation.

Furthermore, we determined the leukocyte count in the peripheral blood of chronically infected mice. We found that it was affected by Isoprinosine in the timeframe of 60$150 \mathrm{dpi}$. Animals that were infected and Isoprinosine-treated had a slightly increased leukocyte count, which continuously decreased later after infection (180-240 dpi).

In contrast, infected but untreated animals had a higher leukocyte count, which may be attributed to the reaction of the immune system to the reactivated virus. The reactivation was suppressed in the Isoprinosine-treated animals. Our data are in agreement with the results published by Pfadenhauer and Glasky (1974).

In the course of chronic infection (60-150 dpi), we also detected an increased amount of neutrophils in infected and Isoprinosine-treated animals, with the maximum at $90 \mathrm{dpi}$, which correlated with the increase of the total leukocyte count in this group of animals.

Following the contact with the virus, the immune system reacts to the infection also by production of antibodies. The titer of virus-neutralizing antibodies increases with the time of infection during the acute infection. These our results are similar to those published by Simas and Efstathiou (1998).

An increased antibody-level during chronic infection may play a role in removing the reactivated virus from infected tissues (Carin et al., 1996). The titer of VN antibodies increased in the course of chronic infection with the time of infection and reached the levels of 16-512. It reached its maximum at 180 and $210 \mathrm{dpi}$ in the group of infected and Isoprinosine-treated mice. The effect of the Isoprinosine treatment on the reactivation suppression subsided at this time, leading to an increase in the antibody level. Our results correlate with the previously published work on positive effect of Isoprinosine on the stimulation of both humoral and cellular immunity, resulting in an increase in CD4+ T cell level in peripheral blood and in the spleen, as well as in the increase of antibody titer (Stenzel et al., 2011).

MHV-68 is related to the EBV and one of their common features is the lymphoproliferation and tumor development in the course of the long-term virus infection. Thus, we set out to examine the lymphoproliferative changes in Balb/c mice infected with MHV-68 in comparison with infected and Isoprinosinetreated mice. Sunil-Chandra and colleagues described lymphoproliferative changes and diseases related to MHV-68 infection in the time span of 165-825 dpi (Sunil-Chandra et al., 1994).

In our hands, tumors developed 180-255 dpi. While $17.5 \%$ of infected and untreated mice developed tumors, only $7.5 \%$ of infected and Isoprinosine-treated mice developed these. No tumors developed in control group. The presence of viral DNA was confirmed by nested PCR in all animals that developed tumors, thus confirming the association of tumor formation and virus infection.
Based on the presented data, we suggest that treatment with Isoprinosine results in lower level of reactivated virus, which is, during gammaherpesvirus infection, usually associated with increase in the count of atypical blood cells and increase in antibody levels. Despite the lower incidence of tumor formation in the Isoprinosine-treated animals, we do not consider our results statistically significant because of the small group of animals in the study. These results, however, confirm our hypothesis of a potentially positive effect of Isoprinosine on the pathogenesis of oncogenic gammaherpesviruses.

Acknowledgement. This paper is published thanks to the financial support of Ewopharma, MUDr. E. Salapová and the projects: VEGA 1/1340/12; Grant UK No. UK/115/2014; Grants VEGA from the Scientific Grant Agency of the Ministry of Education of the Slovak Republic and Slovak Academy of Sciences: VEGA No. 1/0617/15.

\section{References}

Blaškovič D, Stančeková M, Svobodová J, Mistríková J (1980): Isolation of five strains of herpesviruses from two species of free living small rodents. Acta Virol. 24, 468.

Campoli-Richards DM, Sorkin EM, Heel RC (1986): Inosine Pranobex. A preliminary Review of its Pharmacodynamic and Pharmacokinetic Properties and Therapeutic Efficacy. Drugs 32, 383-424.

Čipková-Jarčušková J, Chalupková A, Hrabovská Z, Wágnerová M, Mistríková J (2013): Biological and pathogenetic characterization of different isolates of mouse gammaherpesvirus MHV-68 in context to study of human oncogenic gammaherpesviruses. Acta Virol. 57, 105-112. https://doi. org/10.4149/av $2013 \quad 02 \quad 105$

De Simone C, Albertini F, Almaviva M, Angarano G, Chiodo F, Costigliola P, Delia S, Ferlini A, Gritti F, Mazzarello G (1989): Clinical and immunological assessment in HIV + subjects receiving inosine-pranobex. A randomised, multicentric study. Med. Oncol. Tumor Pharmacother. 6, 63-67. https://doi.org/10.1007/BF02985225

Georgala S, Katoulis AC, Befon A, Georgala C, Rigopoulos D (2006): Oral inosiplex in the treatment of cervical condylomata acuminata: A randomised placebo-controlled trial. BJOG. 113, 1088-1091. https://doi.org/10.1111/ j.1471-0528.2006.01041.x

Ginsberg T, Settineri R, Pfadenhauer E, Glasky AJ (1973): Isoprinosine: suppression of cytopathic effects of influenza A and rhinovirus in tissue culture. ASM 73, 206.

Ginsberg T, Simon LN, Glansky AJ (1978): Isoprinosine: pharmacological and toxicological properties in animals. 7th International Congress of Pharmacology, 16 July 1978. Paris, France. https://doi.org/10.1016/b978-0-08023768-8.51881-8

Gordon P, Ronson B, Brown ER (1974): Anti-herpesvirus action of Isoprinosine. Antimicrob. Agents Chemother. 5, 153-160. https://doi.org/10.1128/AAC.5.2.153 
Gutierrez J, Issacson RS, Koppel BS (2010): Subacute sclerosing panencephalitis: An update. Dev. Med. Child. Neurol. 52,901-907. https://doi.org/10.1111/j.1469-8749.2010.03717.x

Hadden JW, Englard A, Sadlik J R, Hadden EM (1979): The comparative effects of isoprinosine, levamisole, muramyl dipeptide and SM1213 on lymphocyte and macrophage proliferation and activation in vitro. Int. J. Immunopharmacol. 1, 17- 27.

Hernandez-Jauregui P, Gonzalez-Vega D, Cruz-Lavin E, Hernandez-Baumgarten E (1980): In vitro effect of Isoprinosine on rabies virus. Am. J. Vet. Res. 41, 1475-1478.

Hrubiško M (2009): Immunotherapy in outpatient practice - what we can expect from chemical immunomodulatory drugs? Ambulantná Terapia 7, 6-9 (in Slovak).

Chang TW, Weinstein L (1973): Antiviral activity of Isoprinosine in vitro and in vivo. Am. J. Med. Sci. 265, 143-146. https:// doi.org/10.1097/00000441-197302000-00005

Jacobsen PL, Greenspan JS (1982-1983): The effect of Isoprinosine on the PHA response of monocyte-depleted and undepleted peripheral blood mononuclear cells. J. Immunopharmacol. 4, 355-365. https://doi. org/10.3109/08923978209019453

Karimov IZ (2004): Efficiency of groprinosine in the complex treatment of acute virus hepatitis B. Lek Správa 7, 74-77 (in Slovak).

Linhares RE, Wigg MD, Largota MH, Nozawa CM (1989): The in vitro antiviral activity of isoprinosine on simian rotavirus (SA-11). Braz. J. Med. Biol. Res. 22, 1095-1103.

Malaczewska J, Rotkiewicz Z (2005): Effect of Methisoprinol and KLP-602 on virus replication in chicken emryos. Pol. J. Vet. Sci. 8, 289-294.

Matusiak L, Szepietowski J (2010): Inosine pranobex (Groprinosin) in dermatological therapy: What we know till now? Dermatologia Kliniczna 12, 31-36.

Mistríková J, Rašlová H, Mrmusová M, Kúdelová M (2000): A Murine Gammaherpesvirus. Acta Virol. 44, 211-226.

Mohanty KC, Scott CS (1986): Imunotherapy of genital earts with inosine pranobex (imunovir): Preliminary study. Genitourin. Med. 62, 352-355.

Muldoon RL, Menzy L, Jackson GG (1972): Effect of Isoprinosine against influenza and some other viruses causing respiratory diseases. Antimicrob. Agents Chemother. 2, 224-228. https://doi.org/10.1128/AAC.2.3.224

Nakamura T, Miyasaka N, Pope RM, Talal N, Russel IJ (1983): Immunomodulation by isoprinosine effects on in vitro immune functions of lymphocytes from humans with autoimmune diseases. Clin. Exp. Immunol. 52, $67-74$.

Ohnisi H, Kosuzume H, Inaba H, Okura M, Morita Y (1982): Mechanism of host defense suppression induced by viral infection: mode of action of isoprinosine as an antiviral agent. Infect. Immun. 38, 243-250.
Petrova M, Jelev D, Ivanova A, Krastev Z (2010): Isoprinosine affects serum levels in healthy adults. J. Interferon Cytokine Res. 30, 223-227. https://doi.org/10.1089/jir.2009.0057

Petrisková J, Raffajová J, Vrlík M (2002): Laboratory parameters os specific and nonspecific cell-mediated immunity in patients treated by Isoprinosine. Klinická Imunológia a Alergológia 12, 20-23 (in Slovak).

Rickinson AB, Kieff E (1996): Epstein-Barr virus. In Fields BN, Knipe DM and Howley PM (Eds): Fields Virology. Lippincott-Raven Publishers, Philadelphia, pp. 2397-2446.

Rickinson AB, Gregory CD, Murray RJ, Ulaeto DO, Rowe M (1989): Cell-mediated imunity to Epstein-Barr virus and the patogenesis of virus-associated B-cell lymphomas. In $\mathrm{d}$ by N.J. Dimmock NJ, Minor PD (Ed.): Immune Responses. Virus Infections and Disease. IRL Press, Oxford, pp. 59-83.

Sadowska-Wroblewska M, Wroblewska-Graff T, WerynskaPrzybylska J, Rell-Bakalarska M, Kurdybacha J (1988): Isoprinosine in the early pre-erosive stage of rheumatoid arthritis: a pilot study. Z. Rheumatol. 47, 113-116.

Saito F, Ito T, Connett JM, Schaller MA, Carson WF, Hogaboam CM, Rochford R, Kunkel SL (2013): MHV68 Latency Modulates the Host Immune Response to Influenza A Virus. Inflammation 36, 1295-1303. https://doi. org/10.1007/s10753-013-9668-1

Samuel CCH (2011): Adenosine Deaminases Acting on RNAs (ADARs) are both Antiviral and Proviral. Virology 411, 180-193. https://doi.org/10.1016/j.virol.2010.12.004

Simon LN, Glasky AJ (1978): Isoprinosine: an overview. Cancer Treat. Rep. 62, 1963-1969.

Stenzel T, Tykałovski B, Smiałek M, Kwiatkowska-Stenzel A, Koncicki A (2011): The effect of different doses of methisoprinol on the percentage of $\mathrm{CD} 4^{+}$and $\mathrm{CD} 8+\mathrm{T}$ lymphocyte subpopulation and the antibody titers in pigeons immunised against PPMV-1. Pol. J. Vet. Sci. 14, 367-372.

Stevenson PG, Doherty PC (1998): Kinetic analysis of the specific host response to a murine gammaherpesvirus. J. Virol. 72, 943-949.

Sundar SK, Barile G, Menezes J (1985): Isoprinosine enhances the activation of sensitized lymphocytes by Epstein-Barr virus antigens. Int. J. Immunopharmacol. 7, 187-192. https:// doi.org/10.1016/0192-0561(85)90025-6

Sunil-Chandra NP, Efstathiou S, Arno J, Nash AA (1992): Virologi$\mathrm{cal}$ and pathological features of mice infected with murine gammaherpesvirus 68. J. Gen. Virol. 72, 2347-2356. https://doi.org/10.1099/0022-1317-73-9-2347

Sunil-Chandra NP, Arno J, Fazakerley J, Nash AA (1994): Lymphoproliferative disease in mice infected with murine gammaherpes 68. Am. J. Pathol. 145, 818-826.

Tsang KY, Pan JF, Swanger DL, Fudenberg HH (1985): In vitro restoration of immune responses in aging humans by isoprinoisne. Int. J. Immunopharmacol. 7, 199-206. https://doi.org/10.1016/0192-0561(85)90027-X 